\title{
Aplikasi Pembelajaran English Grammar Berbasis Game Android
}

\author{
Maria Bellaniar Ismiati ${ }^{1}$, Latius Hermawan ${ }^{2}$, Paskalina Widiastuti R. ${ }^{3}$ \\ Jalan Bangau No.60, Universitas Katolik Musi Charitas, e-mail: bella@ukmc.ac.id \\ Jalan Bangau No.60, Universitas Katolik Musi Charitas, e-mail: tiuz.hermawan@ukmc.id \\ Jalan Bangau No.60, Universitas Katolik Musi Charitas, e-mail: paskalina_widiastuti@ukmc.id
}

\section{ARTICLE INFO}

Article history:

Received 13 November 2019

Received in revised form 15 January 2020

Accepted 27 January 2020

Available online 31 January 2020

\begin{abstract}
Learning English in class is often carried out in a conventional way such as explaining using a whiteboard, doing practice exercises with pen and paper, and memorizing material from a book / dictionary. Such conventional teaching and learning processes often make students bored and feel the material presented is difficult to understand. One way that can be used to overcome this problem is to create a tool that uses technology, such as games.

Gra-Pe Warrior game which has an adventure game concept with penguins as the main character where each level of the player must answer questions about grammar. Gra-Pe Warrior game has become a new learning that further increases motivation in learning. This is evidenced by the results of a descriptive questionnaire test which shows that $>90 \%$ of respondents are interested because learning in the form of games is more interesting because it is equipped with several questions about grammar at each door when leveling up.
\end{abstract}

Keywords: game, android, english, grammar

\section{Pendahuluan}

Bahasa Inggris telah menjadi salah satu pelajaran wajib dalam bidang pendidikan, yaitu untuk siswa (sekolah) maupun mahasiswa (Perguruan Tinggi). Salah satu Perguruan Tinggi di kota Palembang, yaitu Universitas Katolik Musi Charitas (UKMC) juga menjadikan Bahasa Inggris sebagai mata kuliah wajib bagi seluruh mahasiswa di masing-masing Program Studi. Pembelajaran Bahasa Inggris di kelas sering dilaksanakan dengan cara konvensional seperti menjelaskan menggunakan whiteboard, mengerjakan latihan soal dengan pena dan kertas, dan menghapalkan / mempelajari materi dari suatu buku ataupun kamus. Proses belajar-mengajar yang konvensional seperti itu sering membuat mahasiswa menjadi bosan dan merasa materi yang disampaikan sulit untuk dimengerti. Berdasarkan hasil kuisioner, maka dapat disimpulkan bahwa perlu adanya sesuatu yang baru dalam pembelajaran Bahasa Inggris yang lebih interaktif, menarik, bervariasi, dan membangkitkan semangat / motivasi dalam belajar.

Pembelajaran yang diperlukan sesuai dengan hasil kuisioner tersebut adalah pembelajaran yang mengikuti perkembangan industri 4.0, yaitu menggunakan teknologi dalam proses belajarmengajarnya (mobile education). Berdasarkan kebutuhan yang diperlukan di UKMC, pembelajaran Bahasa Inggris yang menggunakan teknologi adalah grammar (di dalamnya terdapat materi Received November 13, 2019; Revised January 12, 2020; Accepted January 27, 2020 
mengenai tenses) karena materinya sulit dipahami dan membosankan. Pembelajaran grammar yang dibuat dalam penelitian ini adalah berbasis smartphone, yaitu suatu game android. Dalam penerapan di penelitian ini, game ini ditujukan untuk mahasiswa UKMC yang sudah/sedang mengambil mata kuliah Bahasa Inggris (khususnya Structure). Berdasarkan latar belakang dan penjelasan di atas, maka dibuatlah Aplikasi Pembelajaran English Grammar Berbasis Game Android. Game ini diharapkan dapat meningkatkan kemauan dan kemampuan mahasiswa untuk lebih memahami English Grammar. Game ini juga dapat dimainkan tidak hanya saat jam kuliah tetapi juga saat di luar kelas untuk terus mengasah kemampuan grammar-nya.

\subsection{Rumusan Masalah}

Rumusan masalah dari penelitian ini adalah sebagai berikut:

1. Bagaimana membuat Aplikasi Pembelajaran English Grammar Berbasis Game Android dengan materi-materi yang diambil dari mata kuliah Bahasa Inggris (khususnya Structure) di UKMC ?

2. Bagaimana mengetahui bahwa game Gra-Pe Warrior ini dapat menjadi suatu pembelajaran baru yang lebih interaktif, menarik, bervariasi, dan membangkitkan semangat / motivasi dalam belajar?

\subsection{Tujuan}

Adapun tujuan Penelitian ini adalah sebagai berikut

1. Untuk membuat Aplikasi Pembelajaran English Grammar Berbasis Game Android dengan materi-materi yang diambil dari mata kuliah Bahasa Inggris (khususnya Structure) di UKMC.

2. Untuk mengetahui bahwa game Gra-Pe Warrior ini dapat menjadi suatu pembelajaran baru yang lebih interaktif, menarik, bervariasi, dan membangkitkan semangat / motivasi dalam belajar.

\subsection{Studi Pustaka}

1. Aplikasi Pembelajaran / Media Pembelajaran

Menurut [4], aplikasi merupakan penerapan, menyimpan sesuatu hal, data, permasalahan, pekerjaan kedalam suatu sarana atau media yang dapat digunakan untuk menerapkan atau mengimplementasikan hal atau permasalahan yang ada sehingga berubah menjadi suatu bentuk yang baru tanpa menghilangkan nilai-nilai dasar dari hal data, permasalahan, pekerjaan itu sendiri. Dalam Kamus Besar Bahasa Indonesia, pembelajaran diartikan sebagai "suatu proses, perbuatan, cara menjadikan orang atau makhluk hidup belajar" [5]. Sedangkan menurut [6], pengertian pembelajaran adalah serangkaian kegiatan yang dirancang untuk memungkinkan terjadinya proses belajar pada siswa. Dari pengertian tersebut dapat disimpulkan bahwa aplikasi pembelajaran merupakan suatu program yang berfungsi sebagai media yang digunakan dalam proses belajar-mengajar antara pendidik dan murid.

2. Pembelajaran dengan Menggunakan Teknologi

Pembelajaran bahasa Inggris selama ini terdapat yang klasikal di kelas dan terdapat pula seiring dengan perkembangan zaman menggunakan teknologi. Dengan menggunakan teknologi, siswa bisa belajar dengan menggunakan komputer yang dikenal dengan Computer Assisted Language Learning, terdapat pula yang menggunakan aplikasi di handphone yang dikenal dengan MALL (Mobile Assisted Language Learning). [1] menyatakan muncul istilah TELL (Technology Enhanced Language Learning) di tahun 1990an.

3. Pembelajaran Grammar

"Grammar is the system of rules governing the conventional arrangement and relationship of words in a sentence" [2]. Pada perkembangan pembelajaran bahasa Inggris saat ini, pembelajaran grammar mengarah pada form-focused instruction dimana juga berperan dalam komunikasi pada penggunaan grammar [10]. Pembelajaran grammar melihat kebutuhan dan

TRANSFORMATIKA Vol. 17, No. 2, January 2020: 198-206 
tujuan dari pembelajaran grammar. Salah satu teknik dalam pembelajaran grammar yaitu written texts yang berupa melengkapi kalimat dengan verb tenses yang tepat pada latihan grammar [10].

4. Game

Game berasal dari bahasa inggris yang memiliki arti dasar permainan. Permainan dalam hal ini merujuk pada pengertian "kelincahan intelektual". Ada target-target yang ingin dicapai pemainnya. Kelincahan intelektual, pada tingkat tertentu, merupakan ukuran sejauh mana game itu menarik untuk dimainkan secara maksimal. Mengacu pada [12] game harus menghibur pemain, yaitu: Game harus menghadirkan imajinatif, pengalaman koheren, sehingga desainer harus memiliki visi serta menjual dengan baik, sehingga desainer harus mempertimbangkan selera konsumen dan menawarkan tantangan kecerdasan dan pengalaman yang mulus, sehingga desainer harus mengerti teknologi.

5. Android

Android adalah sebuah sistem operasi untuk perangkat mobile berbasis linux yang mencakup sistem operasi, middleware dan aplikasi. Salah satu elemen kunci dari android adalah Dalvik Virtual Machine (DVM). Android berjalan didalam Dalvik Virtual Machine (DVM) bukan di Java Virtual Machine (JVM), sebenarnya banyak persamaannya dengan Java Virtual Machine (JVM) seperti Java ME (Java Mobile Edition), tetapi Android menggunakan Virtual Machine sendiri untuk memastikan bahwa beberapa feature-feature berjalan lebih efisien pada perangkat mobile [15].

6. Model Pengembangan Perangkat Lunak (Sekuensial Linier)

Dalam model ini, pengembangan perangkat lunak dilakukan secara sistematik dan linier, yang dimulai dari aktivitas analisis, desain, pengkodean dan pengujian perangkat lunak. Aktivitas analisis dan desain merupakan bagian dari aktivitas rekayasa sistem. Setiap model analisis yang dihasilkan akan diterjemahkan ke bentuk desain yang bersesuaian [16].

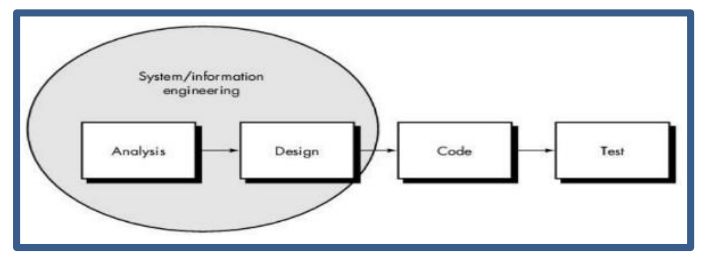

\section{Gambar 1. Model Pengembangan Perangkat Lunak Sekuensial Linier}

\subsection{Studi Literatur / Penelitian Terdahulu}

Penelitian [17] membuat suatu game android yang diberi nama Edugame dan game ini merupakan suatu game edukasi yang mengenalkan serangkaian aktivitas seperti penyusunan kata, pengenalan huruf atau operasi matematika kepada anak-anak. Pada tahap mendesain game ini menggunakan UML dan implementasinya menggunakan platform android. Game ini cocok untuk anak usia 3-7 tahun agar anak-anak dapat belajar secara bebas dan kreatif.

Pengembangan game selanjutnya dilakukan oleh [18] dengan membuat, mendesai, dan mengembangkan "Tales of Mamochi". Game ini merupakan game RPG dengan seorang partner bernama Mamochi yang membantu pemain untuk melawan monster. Tales of Mamochi mempunyai fitur khusus seperti character selection, collection book, battle (PVE), crafting, mamochi evolution, farm, cooking and quest dengan menggunakan grafis 2 dimensi.

Selain game 2 dimensi, peneliti [14] mengembangkan suatu game android bernama "SNAFDROID" dengan grafis 3 dimensi yang akan membuat permainan game lebih menarik. Game ini merupakan suatu snake game yang biasanya dimainkan dalam grafis 2 dimensi tetapi ini dikembangkan dengan lebih interaktif dengan konsep 3 dimensi. Dalam game ini terdapat banyak pilihan environment yang akan menarik minat user. Pengembangan game ini merupakan sesuatu yang baru. 
Peneliti [19] membuat suatu puzzle game dimana seorang pemain bergerak secara kompleks dan mempunyai beberapa alternatif posisi untuk mencari target yang sebenarnya. Suatu metode untuk membuat permainan itu adalah Growing Tree Method. Metode ini membuat suatu pohon dengan banyak cabang yang merupakan bagian dari permainannya. Game ini dibuat dalam platform android agar lebih fleksibel saat akan bermain dengan game ini.

\section{Metode Penelitian}

2.1. Tahapan-tahapan penelitian yang dilakukan disesuaikan dengan tahapan pada model pengembangan perangkat lunak sekuensial linier, yaitu :

1. Analysis

a. Penentuan masalah dan requirement di tempat penelitian

b. Penyebaran kuisioner untuk mendukung latar belakang masalah dalam penelitian

c. Kajian pustaka dan pengumpulan data beserta referensi yang akan digunakan sebagai pendukung penelitian ini

d. Penentuan alat dan bahan yang digunakan dalam membuat game Gra-Pe Warrior

2. Design
a. Perancangan interface untuk Gra-Pe Warrior
b. Perancangan masing-masing level yang akan dimainkan
c. Perancangan asset dan environment yang digunakan

3. Code
a. Pembuatan coding untuk Gra-Pe Warrior
b. Pengecekan bug dan error pada game yang telah dibuat

4. Test

a. Penyerahan game ke beberapa mahasiswa yang sudah/sedang mengambil mata kuliah Bahasa Inggris (Structure)

b. Pengujian Gra-Pe Warrior kepada pengguna, yaitu beberapa mahasiswa yang sudah/sedang mengambil mata kuliah Bahasa Inggris (Penyebaran kuisioner)

c. Pembuatan Laporan Penelitian beserta kesimpulan terhadap hasil penelitian dan pengujian

2.2. Prosedur perancangan yang dilakukan adalah dalam membuat interface dari Gra-Pe Warrior. Proses-proses yang dilakukan dalam perancangan interface game ini adalah :

1. Proses pembuatan skenario untuk game

2. Proses pengumpulan requirement dalam game seperti asset dan environment

3. Proses pengumpulan pertanyaan-pertanyaan yang berupa materi kuliah dalam mata kuliah Structure

4. Proses coding Gra-Pe Warrior

5. Proses uji coba oleh peneliti sebelum diberikan kepada pengguna dan publik

6. Proses pengujian kepada end user yang merupakan tahap terakhir yang dilakukan untuk mendapatkan feedback dari pengguna mengenai aplikasi pembelajaran yang telah dibuat. Pengujian dilakukan kepada beberapa mahasiswa yang sudah/sedang mengambil mata kuliah Bahasa Inggris (Structure) di UKMC dengan menyebarkan kuisioner

2.3. Metode Pengumpulan data yang digunakan dalam penelitian ini adalah sebagai berikut :

a. Pembagian kuisioner untuk mendukung latar belakang penelitian ini.

b. Analisis data hasil kuisioner awal

c. Tinjauan Pustaka (studi pustaka dan studi literatur)

2.4. Analisis Data dilakukan dengan perhitungan statistika deskriptif untuk mendapatkan hasil pengujian game ini ke 33 mahasiswa UKMC yang sudah/sedang mengambil mata kuliah Bahasa Inggris.

TRANSFORMATIKA Vol. 17, No. 2, January 2020: $198-206$ 


\section{Hasil dan Pembahasan}

3.1. Hasil konsep game yang dibuat adalah sebagai berikut.

\section{Inisialisasi Awal}

Game Gra-Pe Warrior ini merupakan permainan bergenre adventure/petualangan, yaitu game yang berupa petualangan suatu karakter penguin yang penuh dengan aksi (berjalan, melompat, dan berjalan merunduk). Genre ini mengutamakan masalah eksplorasi dalam berburu bintang dan makanan penguin, menghindari rintangan yang ada (api unggun, jurang, NPC musuh, jembatan, tanah yang apabila diinjak terlalu lama akan jatuh), serta pemecahan soal-soal mengenai Grammar. Game ini dimainkan oleh 1 pemain yang menggerakkan penguin sampai pada level akhir. Pada saat game dijalankan, akan muncul splash screen yang berisi logo UKMC dan tools yang digunakan. Selanjutnya pemain akan diarahkan ke tampilan awal yaitu menu utama. Di dalam menu utama ini terdapat satu pilihan tombol yaitu tombol Play yang digunakan untuk mulai memainkan game.

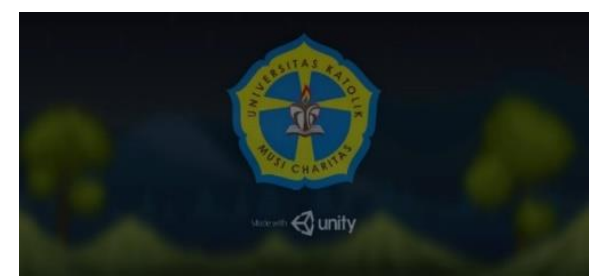

Gambar 2. Splash Screen

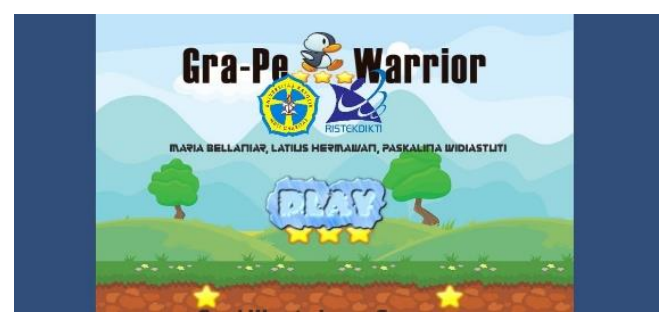

Gambar 3. Tampilan Menu Utama

\section{Aturan-aturan}

Aturan main (rule) pada game Gra-Pe Warrior adalah sebagai berikut :

1. Pada awal permainan, karakter dalam game yaitu penguin akan diposisikan di layout awal level 1.

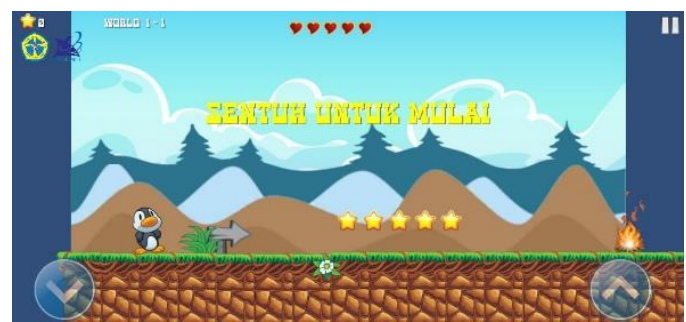

Gambar 4. Layout awal level 1 (World 1-1)

2. Untuk menggerakan karakter, pemain dapat menekan tombol di kanan bawah dan kiri bawah dengan ketentuan sebagai berikut :

Tekan sekali di layer : membuat karakter bergerak maju

: membuat karakter melompat 
: membuat karakter berjalan merunduk

3. Dalam perjalanan, karakter bisa mengumpulkan bintang dan makanan karakter (penguin) untuk menambah poin. Poin akhir diakumulasi dari seberapa banyak bintang yang berhasil didapatkan oleh karakter tersebut (1 bintang poinnya 10) sedangkan makanan untuk menambah hati (bahan bakar/nyawa) karakter.

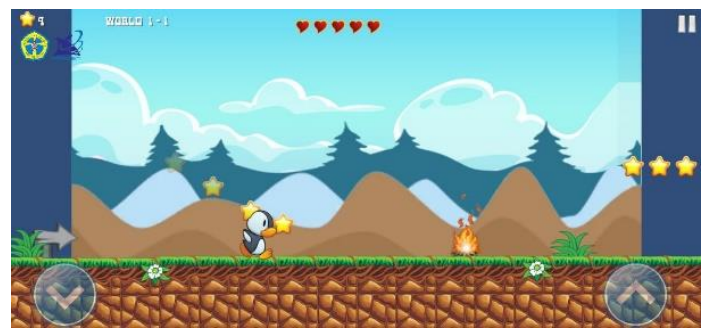

Gambar 5. Karakter saat berhasil mendapatkan bintang

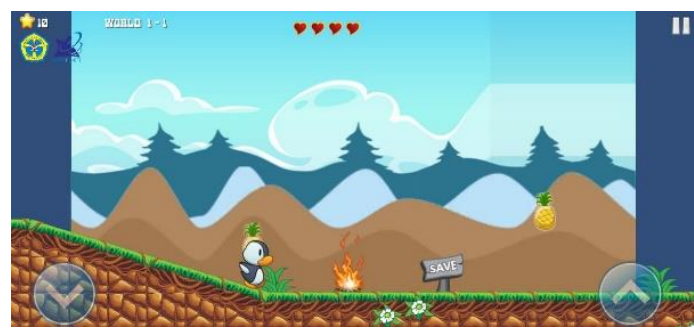

Gambar 6. Karakter saat berhasil mendapatkan makanan (nanas)

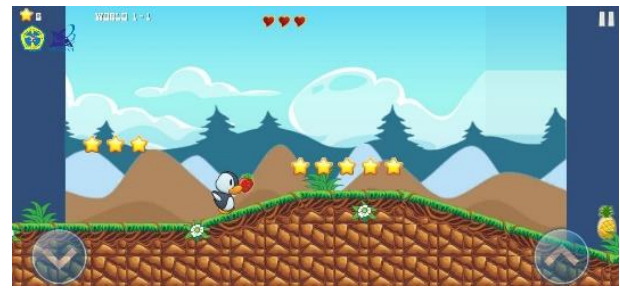

Gambar 7. Karakter saat berhasil mendapatkan makanan (strawberry)

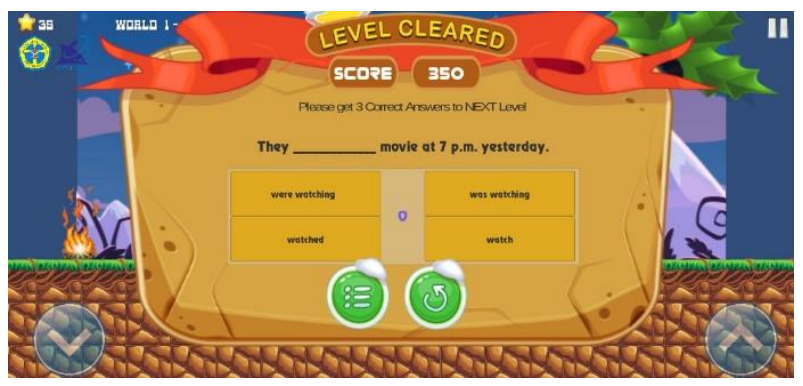

Gambar 8. Karakter saat berhasil mendapatkan 35 bintang

TRANSFORMATIKA Vol. 17, No. 2, January 2020 : 198-206 
4. Ketika pemain berhasil melewati semua rintangan di tiap level, maka pemain akan diperbolehkan masuk ke pintu level selanjutnya dan diberi beberapa pertanyaan mengenai Grammar. Pemain tidak diharuskan menjawab semua pertanyaan dengan benar tetapi diberi kesempatan hanya beberapa pertanyaan saja, contoh jawablah dengan benar hanya 3 pertanyaan dari beberapa pertanyaan yang ditampilkan.

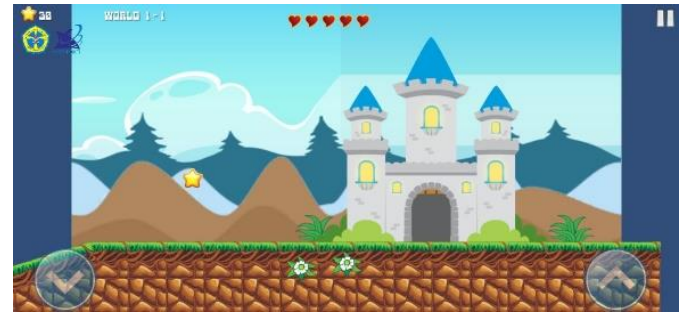

Gambar 9. Pintu Level selanjutnya

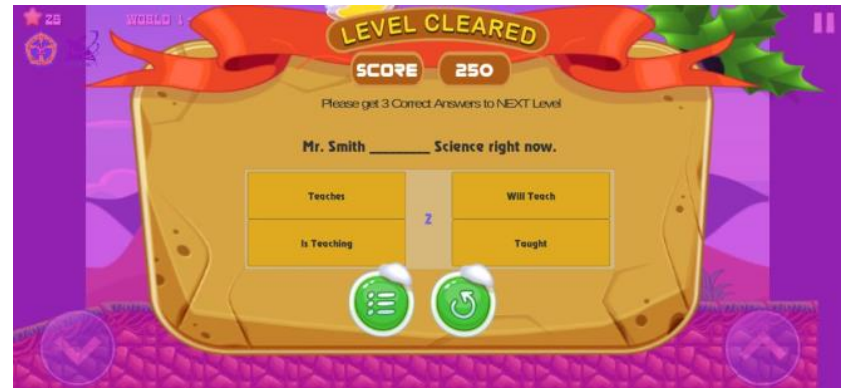

Gambar 10. Contoh Pertanyaan Grammar

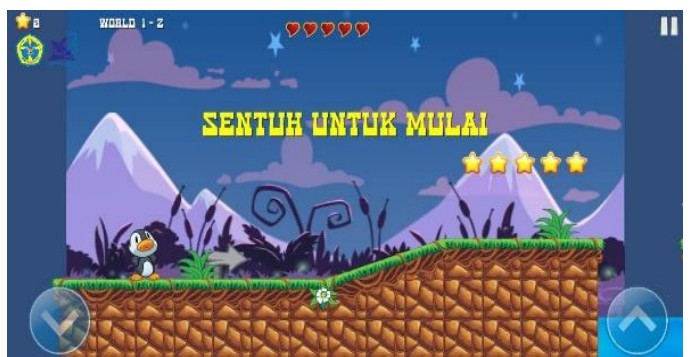

Gambar 11. Karakter memasuki level selanjutnya setelah menjawab pertanyaan (World 1-2)

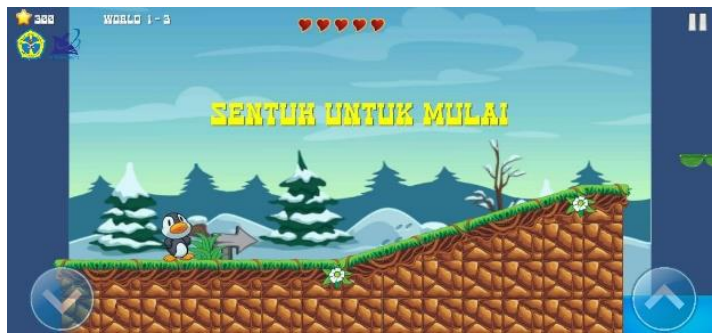

Gambar 12. Karakter memasuki level selanjutnya setelah menjawab pertanyaan (World 1-3) 
5. Ketika ada kegagalan dalam melewati rintangan untuk menyelesaikan suatu level permainan, maka game akan kembali diulangi dari awal. Akan tetapi bila karakter sudah melalui suatu check point, maka game akan diulangi di tempat karakter telah melewati check point tersebut.

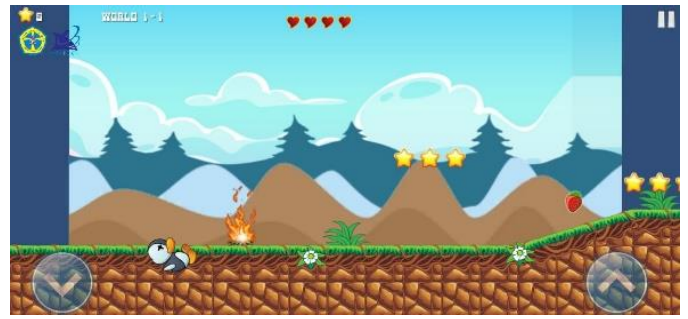

Gambar 13. Karakter gagal dalam melewati rintangan api

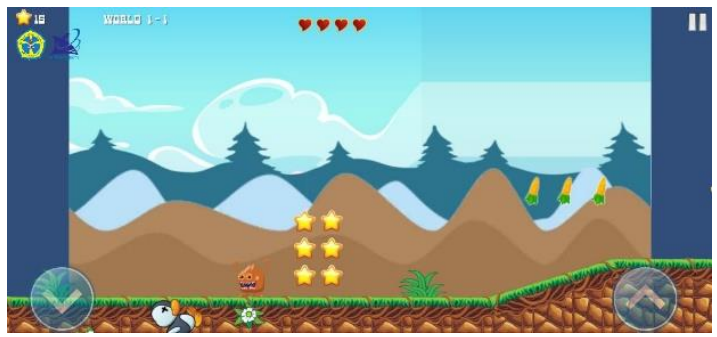

Gambar 14. Karakter gagal dalam melewati rintangan NPC musuh

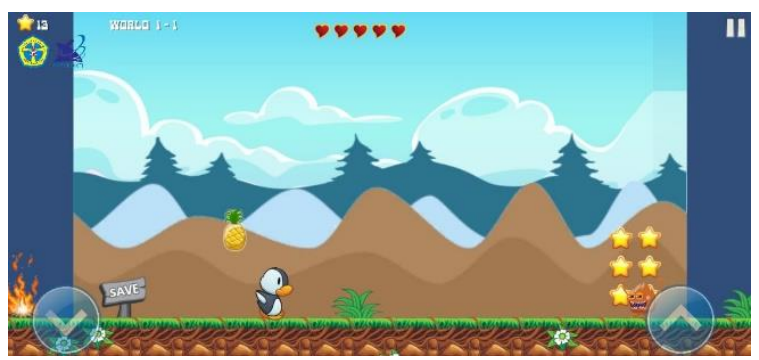

Gambar 15. Tanda save untuk penanda check point

6. Game akan tamat ketika pemain (karakter dalam game) telah berhasil menyelesaikan semua level di tiap bagian (world) dan berhasil menjawab semua pertanyaan Grammar dengan benar.

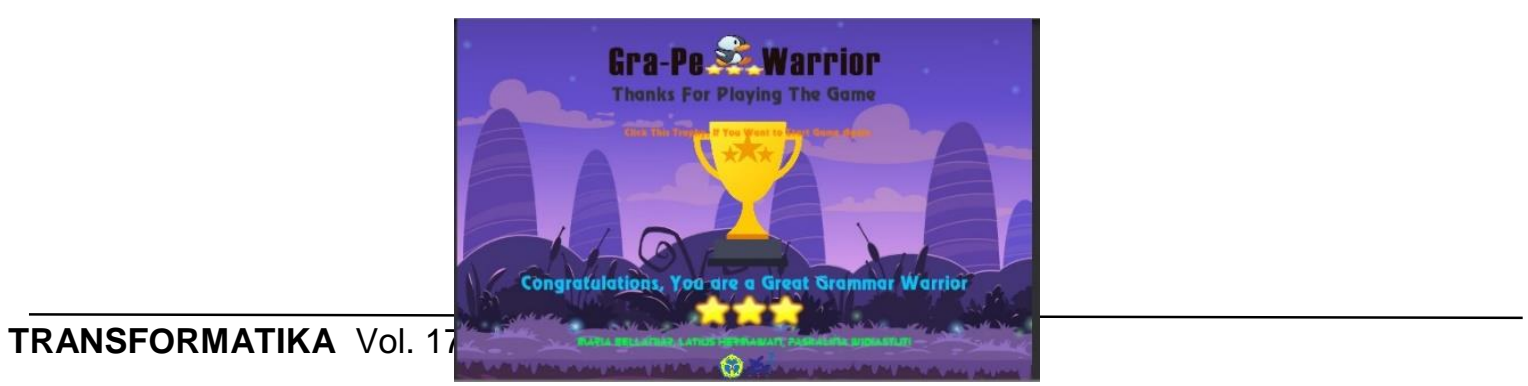


Gambar 16. Tampilan Akhir apabila

\section{Goals}

Tujuan dari game Gra-Pe Warrior

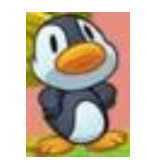

Pemain Berhasil Menang ada di setiap level, mendapatkan bintang untuk menambah poin, mendapatkan makanan penguin untuk menambah hati (life health/nyawa), dan menjawab semua pertanyaan mengenai Grammar di setiap levelnya. Kemudian game akan berakhir ketika pemain sudah berhasil memainkan semua level di tiap bagian / world.

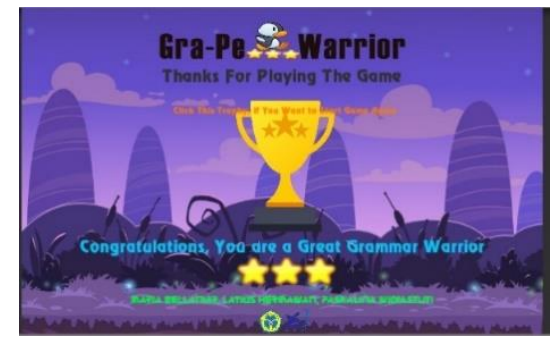

Gambar 17. Goals yang Tercapai

\section{$4 \quad$ Karakter}

Karakter dalam game ini adalah seekor penguin kecil yang berwarna abu-abu, putih, dan orange dan tidak membawa apapun di tangan/badannya.

Gambar 18. Karakter Penguin Tampak samping di Game Gra-Pe Warrior

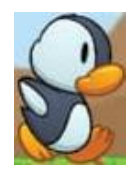

Gambar 19. Karakter Penguin Tampak depan di Game Gra-Pe Warrior

\subsection{Hasil Pengujian Akhir (Kuisioner)}

1. Anda tertarik untuk menggunakan game edukasi ini ?

Berdasarkan pengolahan hasil kuisioner terlihat bahwa lebih banyak mahasiswa yang tertarik untuk menggunakan game edukasi ini dengan persentase sebanyak $94 \%$ sedangkan masih ada beberapa mahasiswa yang tidak tertarik menggunakan game edukasi ini dengan persentase sebanyak 6\%. Hal tersebut menunjukkan bahwa hampir seluruh mahasiswa yang mengisi kuisioner tertarik menggunakan game ini.

2. Apakah tampilan game edukasi menarik?

Berdasarkan pengolahan hasil kuisioner terlihat bahwa lebih banyak mahasiswa yang berpendapat bahwa tampilan game edukasi ini menarik dengan persentase sebanyak $94 \%$ sedangkan masih ada beberapa mahasiswa yang berpendapat bahwa tampilan game edukasi ini tidak menarik dengan persentase sebanyak 6\%. Hal tersebut menunjukkan bahwa hampir seluruh mahasiswa yang mengisi kuisioner ini berpendapat bahwa tampilan game edukasi ini menarik.

3. Apakah game edukasi Gra-Pe Warrior mudah digunakan ?

Berdasarkan pengolahan hasil kuisioner terlihat bahwa lebih banyak mahasiswa yang berpendapat bahwa game edukasi Gra-Pe Warrior ini mudah digunakan dengan persentase sebanyak $85 \%$ sedangkan masih ada beberapa mahasiswa yang berpendapat bahwa game edukasi Gra-Pe Warrior 
ini tidak mudah digunakan dengan persentase sebanyak $15 \%$. Hal tersebut menunjukkan bahwa hampir seluruh mahasiswa yang mengisi kuisioner ini berpendapat bahwa game edukasi Gra-Pe Warrior ini mudah digunakan.

4. Apakah fitur pada game edukasi ini sudah lengkap >

Berdasarkan pengolahan hasil kuisioner terlihat bahwa lebih banyak mahasiswa yang berpendapat bahwa fitur pada game edukasi ini lengkap dengan persentase sebanyak $73 \%$ sedangkan masih ada beberapa mahasiswa yang berpendapat bahwa fitur pada game edukasi ini tidak lengkap dengan persentase sebanyak 27\%. Hal tersebut menunjukkan bahwa hampir seluruh mahasiswa yang mengisi kuisioner ini berpendapat bahwa fitur pada game edukasi ini lengkap.

5. Apakah alur permainan pada game edukasi tersebut menampilkan informasi yang sesuai dengan topik?

Berdasarkan pengolahan hasil kuisioner terlihat bahwa lebih banyak mahasiswa yang berpendapat bahwa tampilan informasi dengan topik pada alur permainan sesuai dengan persentase sebanyak 91\% sedangkan masih ada beberapa mahasiswa yang berpendapat bahwa tampilan informasi dengan topik pada alur permainan tidak sesuai dengan persentase sebanyak $9 \%$. Hal tersebut menunjukkan bahwa hampir seluruh mahasiswa yang mengisi kuisioner ini berpendapat bahwa tampilan informasi dengan topik pada alur permainan sesuai.

6. Apakah informasi yang disajikan sesuai dengan topik ?

Berdasarkan pengolahan hasil kuisioner terlihat bahwa lebih banyak mahasiswa yang berpendapat bahwa penyajian informasi dengan topik telah sesuai dengan persentase sebanyak $91 \%$ sedangkan masih ada beberapa mahasiswa yang berpendapat bahwa penyajian informasi dengan topik tidak sesuai dengan persentase sebanyak 9\%. Hal tersebut menunjukkan bahwa hampir seluruh mahasiswa yang mengisi kuisioner ini berpendapat bahwa penyajian informasi dengan topik telah sesuai.

7. Apakah bahasa dalam game edukasi ini mudah dipahami ?

Berdasarkan pengolahan hasil kuisioner terlihat bahwa lebih banyak mahasiswa yang berpendapat bahwa bahasa dalam game mudah untuk dipahami dengan persentase sebanyak $97 \%$ sedangkan masih ada beberapa mahasiswa yang berpendapat bahwa bahasa dalam game tidak mudah untuk dipahami dengan persentase sebanyak 3\%. Hal tersebut menunjukkan bahwa hampir seluruh mahasiswa yang mengisi kuisioner ini berpendapat bahwa bahasa dalam game mudah untuk dipahami.

8. Apakah isi game edukasi ini mudah dipahami?

Berdasarkan pengolahan hasil kuisioner terlihat bahwa lebih banyak mahasiswa yang berpendapat bahwa isi game edukasi mudah untuk dipahami dengan persentase sebanyak $97 \%$ sedangkan masih ada beberapa mahasiswa yang berpendapat bahwa isi game edukasi tidak mudah untuk dipahami dengan persentase sebanyak 3\%. Hal tersebut menunjukkan bahwa hampir seluruh mahasiswa yang mengisi kuisioner ini berpendapat bahwa isi game edukasi mudah untuk dipahami.

9. Apakah game edukasi ini mendorong anda untuk lebih ingin belajar Grammar ?

Berdasarkan pengolahan hasil kuisioner terlihat bahwa lebih banyak mahasiswa yang lebih terdorong untuk belajar grammar melalui game edukasi ini dengan persentase sebanyak $73 \%$ sedangkan masih ada beberapa mahasiswa yang tidak terdorong untuk lebih belajar grammar melalui game edukasi ini dengan persentase sebanyak $27 \%$. Hal tersebut menunjukkan bahwa hampir seluruh mahasiswa yang mengisi kuisioner ini lebih terdorong untuk belajar grammar melalui game edukasi ini.

10. Apakah game edukasi ini mampu memberikan tambahan pengetahuan anda mengenai Grammar?

Berdasarkan pengolahan hasil kuisioner terlihat bahwa lebih banyak mahasiswa yang berpendapat bahwa game edukasi ini mampu memberikan tambahan pengetahuan mengenai grammar dengan persentase sebanyak $97 \%$ sedangkan masih ada beberapa mahasiswa yang berpendapat bahwa game edukasi ini tidak mampu memberikan tambahan pengetahuan mengenai grammar dengan persentase sebanyak 3\%. Hal tersebut menunjukkan bahwa hampir seluruh mahasiswa yang

TRANSFORMATIKA Vol. 17, No. 2, January 2020 : $198-206$ 
mengisi kuisioner ini berpendapat bahwa game edukasi ini mampu memberikan tambahan pengetahuan mengenai grammar.

\section{Kesimpulan}

Kesimpulan yang dapat ditarik dari penelitian ini setelah peneliti berhasil membuat game GraPe Warrior adalah :

1. Aplikasi Pembelajaran English Grammar Berbasis Game Android telah berhasil dibuat dengan menggunakan tools Unity3d dilengkapi dengan beberapa pertanyaan mengenai grammar di masing-masing pintu saat naik level.

2 Game Gra-Pe Warrior telah menjadi suatu pembelajaran baru yang lebih interaktif, menarik, bervariasi, dan membangkitkan semangat / motivasi dalam belajar. Hal tersebut dibuktikan dengan hasil pengujian kuisioner secara deskriptif yang menunjukkan bahwa $>90 \%$ responden tertarik karena pembelajaran dalam bentuk game lebih menarik.

\section{References}

[1] Korucu, A.T. \& Alkan, A. (2011). Differences between m-learning (mobile learning) and elearning, basic terminology and usage of m-learning in education. Procedia Social and Behavioral Sciences 15 (2011), pp. 1925-1930.2.

[2] Sukasame, N., Kantho, S. PenneeNarrot. (2014). A study of errors in learning English Grammatical Structures on Tenses on MatthayomSuksa 4 Students of The Demonstration School, KhonKaen University. Procedia Social and Behavioral Sciences 116 (2014), pp. 1934 - 1939.

[3] Quan-yin, Z., Yin, J., Chengjie, X., Rui. G. (2011). A UML Model for Mobile Game on the Android OS. Procedia Engineering 24 (2011), pp. 313 - 318. Katsuhiko Ogata.

[4] Jogiyanto. 2001. Analisis \& Desain Sistem Informasi : pendekatan terstruktur teori dan praktek aplikasi bisnis. Andi, Yogyakarta

[5] Balai Pustaka. 1995. Kamus Besar Bahasa Indonesia, Edisi Kedua : hal.15. Jakarta: Depdikbud.

[6] Winataputra, Udin. S. dkk. (2008). Materi dan Pembelajaran PKN SD. Jakarta: Universitas Terbuka.

[10] Brown, H.D. (2007). Principles of Language Learning and Teaching: fifth edition. New York: Pearson Education, Inc.

[12] Hendrawan, Y.F. (2018). A Maze Game on Android Using Growing Tree Method. Journal of Physics: Conference Series 953012148.

[14] Panwar, P, Vala, N., Rajpal, K., Pandey, H.M. (2012). Developing 3D Game for Android OS: "SNAFDROID". International Journal of Machine Learning and Computing, Vol. 2, No. 5, October 2012.

[15] Kadir, Abdul., (2013), From Zero to A Pro - Pemrograman Aplikasi Android. Andi, Yogyakarta.

[16] Pressman, Roger S. (2012). Rekayasa Perangkat Lunak : Pendekatan Praktisi. (Buku Satu). Yogyakarta : Andi Offset.

[17] Hssina B, Erritali M. (2014). Edugame an Android game for teaching children. International Journal of Innovation and Applied Vol. 9 No. 4 Dec. 2014, pp. 1531-1540

[18] Kurniati A, Nadia. (2015). Game Development "Tales of Mamochi" With Role Playing Game Concept Based on Android. International Conference on Computer Science and Computational Intelligence Procedia Computer Science 59 ( 2015 ) 392 - 399

[19] Panwar N, Vala N. (2012). Developing 3D Game for Android OS: "SNAFDROID". International Journal of Machine Learning and Computing, Vol. 2, No. 5, October 2012 